natsionalnogo universytetu imeni V.I. Vernandskogo. Ser. Filologia. Sotsialni komunikatsii. Tom 31 (70). № 2. Chastyna 3, 46-51.

Golovenko, V. V., Zaluzhna, O. O. (2019). Semantychni osoblyvosti otsinnoii sensornoii leksysy v ogliadakh ukrayinskykh strav ta produktiv kharchuvannia (na materiali youtube video anglomovnykh blogeriv) [Semantic peculiarities of evaluative sensory lexicon in the review of Ukrainian dishes and food (on the material of YouTube video of English speaking bloggers)]. Visnyk studentskogo naukovogo tovarystva Donetskogo natsionalnogo universytetu imeni Vasylia Stusa. / red. kol. Khadzhinov I.V. (golova) ta in. Vinnytsia: DonNU imeni Vasylia Stusa, Vyp. 11, T.2, 98-103.

Voloshyna, O. V. (2021). Leksyka vidchuttia yak zasib vyrazhennia sensornoii otsinky ta ii konotatyvni vlastyvosti [Vovabulary of sensation as a means of expression of sensorial assessment and its connotative characteristics]. Naukovi zapysky Vinnytskogo natsionalnogo agrarnogo universytetu. Ser. Sotsialnogumanitarni nauky. Vyp. 2, 51-58. URL: http://nbuv.gov.ua/UJRN/naukzv_2013_2_7. (Last accessed: 11.03.2021).

Samilyk, T. O. (2020). Model synesteziynykh metafor (slukhovykh, zorovykh, smakovykh, taktylnykh ta niukhovykh) vidchuttiv v suchasnii anglomovnii prozi. [A model of synesthetic metaphors (auditative, visual, degustative, heptical and olfactory) of sensations in the modern English prose]. Perekladatski innovatsii: materialy X Vseukrayinskoii studentskoii naukovo-praktychnoii konferentsii, m. Sumy, 20-21 bereznia 2020 r. I redkol. S. O. Shvachko, I. K. Kobiakova, O. O. Zhulavska, ta in. Sumy: Sumskii derzhavnyi universytet, 163165. URL: https://ifsk.sumdu.edu.ua/images/doc/PI_IFSK_2020.pdf (Last accessed: 14.03.2021).

Sirenko, A.-I. Yu. (2020). Model synesteziynykh (taktylnykh i smakovykh) metafor v suchasnii anglomovnii prozi. [A model of synesthetic (heptical and degustative) metaphors of sensations in the modern English prose]. Perekladatski innovatsii: materialy X Vseukrayinskoii studentskoii naukovo-praktychnoii konferentsii, m. Sumy, 20-21 bereznia 2020 r. / redkol. S. O. Shvachko, I. K. Kobiakova, O. O. Zhulavska, ta in. Sumy: Sumskii derzhavnyi universytet, 165-166. URL: https://ifsk.sumdu.edu.ua/images/doc/ PI_IFSK_2020.pdf (Last accessed: 14.03.2021).

Kuzmenko, Yu. G. (2007). Poniattia sensorno-chuttievoii sfery v riznykh naukovykh paradygmakh. [The notion of sensorial - sensitive sphere in various scientific paradigms]. Problemy semantyky, pragmatyky ta kognitivnoii lingvistyky : zb. nauk. pr. M-vo osvity I nauky Ukrayiny, Kyyivskii nats. un-t im. T. Shevchenka. K.: LOGOS, Vyp. 12, 234-238.

Cherepanov, M. V. (2001). Fenomen razvitiya yazyka v interpretatsii V. Gumbolda, I. A. Boduena de Kurtene i N. V. Krushevskogo. [Language development phenomenon in the interpretation of V. Humbold, I. A. Boduen de Courtene, N. V. Krushevsky]. Boduen de Kurtene i sovremiennaia lingvistika : Boduenovskiye chteniya : Mezhdunar. nauch. konf., 11-13 dekabria 2001 goda, Kazan: trudy i matierialy : v 2 t. / pod obshch. red. K. R. Galiullina, G. A. Nikolayeva. Kazan: Izd-vo Kazan. un-ta, T. 1, 35-37.

Kolpakova, H. V. (2003). Sinonimia v leksikografii [Synonymy in Lexicography]. Sopostavitelnaia filologia i polilingvism: zb. nauch. trudov Vseros. nauchno-praktich. konf. v Kazanskom un-tie, 29-31 oktiabria 2002 goda. / pod obshch. red. A. A. Aminovoi, N. A. Andramonovoi. Kazan: KGU, 95-102.

\title{
INTERPRETING DETACHED CONSTRUCTIONS WITH EXPLICIT SUBJECT THROUGH THE PRISM OF RELATED TERMS ІНТЕРПРЕТАЦІЯ ВІДОКРЕМЛЕНИХ НЕОСОБОВОДІССЛІВНИХ І

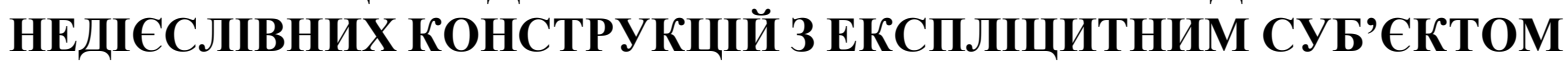 КРІЗЬ ПРИЗМУ СУМІЖНИХ ГРАМАТИЧНИХ ТЕРМІНІВ І ПОНЯТЬ
}

\author{
Вікторія ЖУКОВСЬКА \\ Київський національний лінгвістичний університет \\ victoriazhukovska@gmail.com \\ ORCID ID 0000-0002-4622-4435
}

This article provides a comprehensive account of the English detached nonfinite and nonverbal constructions with the explicit subject within the framework of construction grammar. The study 
overviews the terms utilized in Western grammatical studies to nominate the investigated syntactic structures. Depending on the ontological and gnoseological assumptions of a particular linguistic approach, the analyzed terms highlight specific aspects of the syntactic structures under study (morphosyntactic features, syntactic functions, the subject's case, coreference with the matrix clause, intonation and punctuation marking), and, therefore, cannot fully reveal the nature of the given syntactic phenomenon. The paper discusses the advantages of the term "detached nonfinite and nonverbal constructions with the explicit subject" for cognitive and quantitative operationalization and theoretical substantiation of the examined structures. The component construction is used in the interpretation of the cognitive construction grammar and defined as a noncompositional language sign, a complex pairing of form and meaning, where some aspects of the forms or the meanings cannot be derived from the form and the meaning of its components or from other existing constructions. In present-day English detached [aug/øaug $\left[\operatorname{Subj}_{\mathrm{NP}}\right]\left[\mathrm{Pred}_{\mathrm{NF} / \mathrm{VL}}\right]$ ] constructions constitute a taxonomic constructional network represented through a multiple hierarchy of adjunct clauses combined with the plane of detachment. The network of the analyzed constructions is developed around the constructional schema, represented by the construction of the highest degree of schematicity and abstraction (macro-construction). The features of the macro-construction are inherited by the constructions of a lower level - meso-constructions and individual microconstructions and are reflected in the specific realized constructions - constructs.

Key words: construction, construction grammar, detached syntactic structures.

Статтю присвячено інтерпретації англійських відокремлених неособоводієслівних i недієслівних конструкцій 3 експліцитним суб’єктом із позиції конструкційного підходу. Здійснено систематизацію варіантів найменувань неособоводієслівних i недієслівних синтаксичних утворень з експліцитним суб'єктом у західних граматичних студіях. 3'ясовано, що залежно від онтологічних та гносеологічних настанов конкретного лінгвістичного підходу засвідчені найменування акцентують певні аспекти досліджуваних синтаксичних структур (морфосинтаксичні характеристики, синтаксичну функцію, відмінок суб'єкту, відносини 3 пропозицією/ конституентом матричної клаузи, інтонаційне та пунктуаційне оформлення) i характеризуються неповнотою розкриття природи аналізованого синтаксичного феномену. Обгрунтовано переваги поняття “відокремлені неособоводієслівні та недієслівні конструкції з експліцитним суб'єктом” для когнітивно-квантитативної операціоналізації і теоретичної актуалізації досліджуваних синтаксичних утворень. У складі запропонованого поняття компонент конструкиія використовується у його розумінні конструкційним напрямом когнітивних досліджень та визначається як некомпозиційний мовний знак, що характеризується єдністю форми та змісту (значення/ функції), в якому певний аспект плану вираження (форми) або плану змісту (значення/ функції) не визначається з форми і змісту його компонентів чи 3 інших наразі наявних у мові конструкцій. У сучасній англійській мові відокремлені [aug/øaug $\left[\operatorname{Subj}_{\mathrm{NP}}\right]\left[\mathrm{Pred}_{\mathrm{NF} / \mathrm{VL}}\right]$ ]-конструкцї̈ утворюють таксономічну конструкційну мережу, яка репрезентується через множинну ієрархію ад'юнктних типів клауз, поєднану 3 планом відокремлення. Мережа аналізованих конструкцій розгортається навколо конструкційної схеми, представленої конструкцією найвищого ступеня схематичності та абстрактності - макро-конструкцією, ознаки якої успадковуються менш абстрактними мезоконструкціями та індивідуальними мікро-конструкціями й втілюються у конкретних реалізованих конструкціях - конструктах.

Ключові слова: конструкція, граматика конструкцій, відокремлені синтаксичні структури, неособоводієслівні синтаксичні утворення, недієслівні синтаксичні утворення.

Вступ. Вивчення складних реченнєвих утворень та їхніх складників належить до найактуальніших питань сучасної граматики 3 огляду на вагомі зрушення, що відбуваються у мовознавстві під впливом новітніх теоретичних моделей, зокрема когнітивно-квантитативного підходу у лінгвістичних 
дослідженнях, що охоплює когнітивно-конструкиійні (Ch. Fillmore, P. Kay, C. O’Connor (1988), H. C. Boas, M. Fried (2005), A. Bergs, G. Diewald (2008), A.E. Goldberg (1995, 2006, 2019) та ін.), корпусо-орієнтовані (P. Baker (2010), W. J. Crawford, E. Csomay (2016), A. Stefanowitsch (2020) та ін.) та лінгвоквантитативні (S. Th. Gries, A. Stefanowitsch (2004, 2013), S.Th. Gries (2015), V. Brezina (2018) та ін.) дослідження. Пріоритетними напрямами нинішніх граматичних студій $є$ вивчення кола питань, пов'язаних із розкриттям природи мовних явищ у синхронному аспекті, зокрема з метою аналізу варіативності формальних, семантичних і функціональних властивостей окремих граматичних одиниць (Л.А. Долгополова, І.Є. Снісаренко, М.В. Полховська та ін.) та граматичних підсистем (I.P. Буніятова, А.П. Загнітко, Т.І. Домброван та ін.).

Однією 3 актуальних проблем граматичної теорії, яка потребує опрацювання з позицій новітніх теорій мови, є висвітлення системно-мовних, дистрибутивних та функційно-прагматичних характеристик таких складних синтаксичних утворень як відокремлені неособоводієслівні (nonfinite) та недієслівні (nonverbal) клаузи 3 експліцитно вираженим суб'єктом, що $\epsilon$ аломорфними засобами вираження відокремлених адвербіальних структур сучасної англійської мови (Корунецьь, 2004, с. 372-373).

Окреслені синтаксичні утворення $€$ особливими синтаксичними утвореннями англійського синтаксису 3 відмінними від організації інших структур принципами і законами побудови. Ці синтаксичні одиниці є вториннопредикативними комплексами бінарної структури [NP XP], в яких експлікований вторинний суб'єкт, відмінний від суб'єкту матричної клаузи, виражений номінативною групою (NP), а вторинний предикат (XP) - неособовою формою дієслова (Participle I, Participle II, to-Infinitive) або недієслівною частиною мови $(N P, A P, A d v P, P P)$. Аналізовані утворення приєднуються до матричної клаузи за допомогою спеціальних сполучних слів (аугменторів) (with, without, what with, despite, but та and) або безсполучниково, як-от:

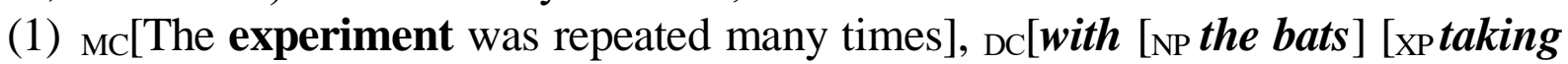
turns to be the starved victim]]] (BNC-BYU, ARR) (British National Corpus).

(2) $\mathrm{MC}_{\mathrm{H}}\left[\mathrm{He}\right.$ clutched at a rail and held on], $\mathrm{DC}\left[\mathrm{NP}_{\mathrm{NP}}\right.$ heart] [XP thumping]], ${ }_{\mathrm{DC}}\left[\left[\mathrm{NP}_{\mathrm{P}}\right.\right.$ the blood $]$ [XP pounding in his ears $\left.]\right],{ }_{\mathrm{DC}}\left[\mathrm{N}_{\mathrm{NP}}\right.$ his mind $]$ [XP wailing for mercy $\left.]\right]$ (BNC-BYU, B1X) (British National Corpus).

Аналіз останніх публікацій. Специфіка окреслених синтаксичних утворень як об'єкта дослідження вітчизняних та закордонних граматичних студій полягає у тому, що їхні окремі аспекти привертали увагу практично всіх лінгвістичних напрямів і шкіл: традиційної граматики (Stump (1985), Попович (1990), Nakagawa (2008), Kortmann (2013) та ін.); генеративної граматики (Riemsdijk (1978), McCawley (1983), Felser, Britain (2007) та ін.); системнофункиіональної граматики (He, Yang (2015), Khamesian (2016) та ін.); корпусобазованої лінгвістики (Duggley, Dion-Girardeau (2015), He, Yang (2015), Fonteyn, van de Pol (2015) та ін.) й конструкиійної граматики (Riehemann, Bender (1999), Bouzada-Jabois, Pérez-Guerra (2016) та ін.). Наслідком такого дослідницького інтересу $\epsilon$, 3 одного боку, достатньо повно окреслений науковий контекст вивчення зазначеної проблематики, а 3 іншого, - термінологічна 
невпорядкованість, що стосується найменування цих синтаксичних одиниць, та відсутність чітких критеріїв їхнього виокремлення і класифікації. Залежно від дослідницького контексту досліджувані синтаксичні утворення відносять до різних термінів і понять. У цьому аспекті особливої актуальності набуває проблема термінологічного витлумачення поняття “відокремлені неособоводієслівні та недієслівні конструкції з експліцитнимм суб'єктом” 3 опертям на суміжні граматичні терміни та поняття, що дасть змогу досягти термінологічної і методологічної визначеності дослідження.

Метою запропонованої статті є інтерпретація поняття “відокремлені неособоводієслівні та недієслівні конструкції з експліцитним суб”єктом” із позиції когнітивно-конструкційного підходу у сучасних лінгвістичних дослідженнях. Завдання дослідження включають: 1) систематизацію варіантів найменувань неособоводієслівних i недієслівних синтаксичних утворень 3 експліцитним суб'єктом у західних граматичних студіях, визначення поняттєвих обсягів відповідних лінгвістичних понять та окреслення сутнісних розбіжностей, що не дозволяють адекватно здійснити ідентифікацію та верифікацію досліджуваних синтаксичних утворень; 2) термінологічне витлумачення поняття “відокремлені неособоводієслівні та недієслівні конструкції 3 експліцитним суб'єктом” та обгрунтування його переваг для когнітивно-квантитативної операціоналізації означених синтаксичних одиниць.

Методи дослідження включають аналіз, систематизацію, класифікацію та елементи методу моделювання формально-семантичних властивостей граматичної конструкції у термінах когнітивно-конструкційного напряму.

Результати та обговорення. Термінологічне позначення неособоводієслівних і недієслівних клауз 3 експлікованим суб'єктом не отримало однозначного вирішення у граматичних студіях. Конвенційно аналізовані структури номінуються як “абсолютні конструкціï” (absolute constructions) (від латинського absolūtum - “вільний”, "незалежний”, “непов'язаний” (Wheelock, 2005, c. 155-157), “що знаходиться поза синтаксичним зв’язком" (Бархударов, 1966, с. 134; Ильиш, 1971, с. 260; Jespersen, 1984, с. 126; Quirk, Greenbaum, Leech i Svartvik, 1985, c. 1120) або ж “анормально поєднаний 3 рештою речення” (Crystal, 2008, c. 2)), проте огляд західних публікацій кінця ХІХ століття до сучасності виявив паралельне вживання принаймні двадцяти семи варіантів найменувань означених синтаксичних одиниць. Засвідчені номінації було розподілено на дві групи: номінації, у складі яких присутній лексичний елемент “absolute” (група “absolute + ”), та номінації, в яких цей елемент відсутній (“absolute - ”). Проаналізувавши кількісний склад виокремлених груп, встановлено, що номінації з елементом “абсолютний” (absolute, absolutive) переважають у граматичних працях. Група “absolute + ” включає дев’ятнадцять варіантів найменувань, як-от: “absolute constructions” (Berent (1973), McCawley (1983), Mitchel (1985), Stump (1985) та ін.), “absolute participles” (Callaway (1890), Ross (1893)), “absolute clause” (Quirk et al. (1985), Biber et al. (1999), He (2013)), "absolute nominative" (Curme (1931), "absolute participle construction" (Zandvoort (1972)), “absolute free adjuncts” (Kruisinga (1932), Beukema (1980)), “absolute structures” (Annema (1924), Ervin (1968)), “absolutes” (Berent (1973), 
(1975), Stump (1985), Haff (2012), Kortmann (2013), Martinčič (2014)), “absolute phrases" (Dini (1994), Kolln (1994)), "nominative absolute”, "accusative absolutes" (Nakagawa (2011) Tanaka T. (2005)) та ін. т. Натомість група номінацій “absolute - "є менш представленою і включає такі номінації як "nехиs tertiary" (Jespersen (1949)), "closed adjuncts" (Fabricius-Hansen, Haug, Sœbø (2012)), "gerundivized clauses" (Talmy (1978)), "supplements" (Huddleston, Pullum (2002)), "detached constructions" (Combett (1998)), "'detached' (adverbial) participle clauses" (Ingrid (2002)) та "detached adjuncts" (Burton-Roberts (2006)).

Залежно від онтологічних i гносеологічних настанов конкретного лінгвістичного підходу кожне із засвідчених найменувань акцентує певні аспекти досліджуваних синтаксичних структур (морфосинтаксичні характеристики, синтаксичну функцію, відмінок суб'єкту, відносини 3 пропозицією/ конституентом матричної клаузи, інтонаційне та пунктуаційне оформлення) $\mathrm{i}$, як наслідок, характеризується неповнотою розкриття природи аналізованого синтаксичного феномену. До прикладу, номінація "gerundivized clauses" (Talmy, 1978) підкреслює, що вершинним елементом виступає герундій. У деяких граматиках ця номінація вживається на позначення іншої синтаксичної структури - номінативні -ing клаузи (Kortmann, 1991, c. 19). По суті, це найменування $\epsilon$ неприйнятним, оскільки у сучасній англійській мові роль предикату неособоводієслівних підрядних клауз з експліцитним суб'єктом виконує дієприкметник теперішнього часу, а не герундій. Крім того, у цьому найменуванні не беруться до уваги синтаксичні утворення 3 іншими типами неособоводієслівних та недієслівних предикатів. 3 огляду на існування недієслівних типів підрядних клауз з експліцитним суб'єктом не вповні доречними вважаємо терміни "participial absolutes", "absolute participle construction" (Zandvoort, 1975; Loporcaro, 2003), які використовуються на позначення відмінних синтаксичних явищ (автогіпонімія): 1) абсолютних дієприкметникових конструкцій, що характеризуються відсутністю або наявністю кореференційного зв'язку з головним реченням, контролю суб'єкта матричної клаузи; 2) дієприкметникових зворотів (дієприкметникових обставинних комплементів (participial circumstantial complement) (Loporcaro, 2003, c. 202-203), що включають залежні та абсолютні дієприкметникові звороти (див. Табл.1):

Відмінності у трактуванні поняття "абсолютний"

Таблиияя 1

\begin{tabular}{|c|c|c|c|}
\hline \multicolumn{2}{|c|}{ “абсолютний” } & \multicolumn{2}{|c|}{ "абсолютний” } \\
\hline \multicolumn{2}{|c|}{$\begin{array}{c}\text { participial absolute } \\
\text { (=абсолютний })\end{array}$} & $\begin{array}{c}\text { participial circumstantial complement } \\
(=\mathbf{P C C})\end{array}$ \\
\hline $\begin{array}{c}\text { некореферентний } \\
\text { (non-controlled) }\end{array}$ & $\begin{array}{c}\text { кореферентний } \\
\text { (controlled) }\end{array}$ & $\begin{array}{c}\text { абсолютний } \\
\text { (absloute) }\end{array}$ & $\begin{array}{c}\text { залежний } \\
\text { (dependent) }\end{array}$ \\
\hline
\end{tabular}

Не зважаючи на традиційність і конвенційність, номінації з елементами "absolute" і “absolutive” є доволі оманливими в аспекті розуміння граматичної природи синтаксичних одиниць, що ними позначаються. До прикладу, дослідники (Thompson, Longacre i Hwang, 2007, c. 264) поняттям "absolutive clauses" дефінують підрядні клаузи, які відповідають таким умовам: 1) клауза лінгвально маркована як підрядна; 2) відсутній експліцитний зв'язок між матричною i 
підрядною клаузами; звідси 3) інтерпретація зв’язку між матричною і підрядною клаузами залежить від прагматичного i лінгвістичного контексту. Проте, зважаючи на можливість у сучасній англійській мові маркувати синтаксичну підпорядкованість клаузи номіналізацією дієслова, а не лише за допомогою лінгвального вираження підрядних відношень, до “absolutive clauses” відносяться як підрядні неособово-дієслівні й недієслівні клаузи з власним суб'єктом, так і без нього ("free adjuncts”). Крім того, вказана відсутність експліцитного зв'язку між матричною і підрядною клаузами не означає “відірваність” чи відсутність будьякого зв’ язку. Між матричною і підрядною клаузами наявні різноманітні смислові зв'язки (Алексеева, 2011). У цьому аспекті слушною є думка Б. Кортмана (Kortmann, 1991, c. 20), який вважає, що вживання понять “absolute” i “absolutive” у трактуванні авторів (Thompson, Longacre $i$ Hwang, 2007) призводить до розмитості первинної мотивації класифікувати певну структуру як абсолютну. Оригінальне потрактування поняття “абсолютний” стосується його розуміння як відмінкової маркованості суб’єкта-NP в неособово-дієслівних та недієслівних клаузах. Абсолютний відмінок (casus absolutus) не повинен керуватися дієсловом у матричній клаузі, як, наприклад, у латинському ablativus absolutus. На противагу, критерієм виокремлення латинського participium coniunctum $\epsilon$ керований особовим дієсловом відмінок його суб'єкта. Крім того, суб'єктом participium coniunctum є матричний суб'єкт, а ablativus absolutus не поділяє жодного аргумента з матричною клаузою та має власний експлікований суб'єкт. Як зазначає В. Ярцева, “незалежність” абсолютної конструкції виникає не через відсутність ії синтаксичного зв’язку з матричним реченням - такий зв'язок все одно є у будь-якому випадку - а через те, що абсолютний дієприкметниковий зворот має у своєму складі вказівку на суб'єкт відмінний від суб'єкта головного складу речення (Ярцуева, 1961, с. 162). Водночас така відмінність є лише у поверхневій структурі, оскільки латинський ablativus absolutus, як і будь-який інший тип абсолютної конструкції, не виключає логічний зв'язок, а у деяких випадках і повну кореференцію, між іiі суб'єктом та суб'єктом матричної клаузи (Kortmann, 1991, c. 21). Погоджуємося 3 А. Руппель, яка переконана, що у загальному значенні “не пов'язані, граматично незалежні від решти речення", абсолютні конструкції $є$ не більш абсолютними, ніж багато інших обставин часу чи місця (Ruppel, 2013, c.7). 3 огляду на наявність логічного зв’язку між абсолютною конструкцією та матричним реченням Дж. Айкен пропонує визнати абсолютним просте самостійне речення та його еквіваленти (Aiken, 1933 проциитований у працчі Алексеєвої, 2001, с. 114).

Саме відсутність спільного аргумента в абсолютної конструкції та матричної клаузи $є$ причиною аблативного маркування суб'єкта-NP неособоводієслівної клаузи та визначення абсолютної конструкції периферійним членом речення (Kortmann, 1991, c. 21). Звідси за визначенням, якщо у конструкції відсутній експлікований суб'єкт- $N P$, така конструкція не може бути віднесена до абсолютних конструкцій.

Номінація “absolute participle construction” також є дискусійною, адже “absolute” у цьому випадку не стосується відмінкового маркування дієприкметника. Як вже йшлося вище, у латинському ablativus absolutus 
маркування абсолютним відмінком вершини предикативного елемента конструкції, де дієприкметник є лише одним із можливих варіантів, сигналізує передовсім узгодження з суб'єктом абсолютної конструкції (Zandvoort, 1975, c. 37; Kortmann, 1991, c. 22).

У сучасній англійській мові прономінальні (pronominal) суб’ єкти абсолютних конструкцій мають два відмінкові маркування: (стандартний) номінативний та (нестандартний) об'єктний відмінки (Curme, 1931, c. 152), а непрономінальні (nonpronominal) суб'єкти немарковані в аспекті відмінку (Curme, 1931, c. 154; Visser, 1972, c. 1148; Jespersen, 1984, c. 126; Kortmann, 1991, c. 12). Звідси номінації "nominative absolute(s)", “nominative absolute construction”, як і номінації accusative absolutes релевантні лише для частини абсолютних конструкцій 3 прономінальним суб'єктом. У цілому, вказівка на відмінкове маркування суб'єкта абсолютних конструкцій $є$ нерелевантною для сучасної англійської мови, виступаючи радше як критерій специфікації, а не класифікації.

Номінації “absolute adjuncts”, "absolute free adjuncts", "absolute adjunct constructions” акцентують синтаксичну функцію цих одиниць. Утім з огляду на той факт, що крім адвербіальної функції означені синтаксичні утворення виконують низку інших функцій (Sakakibara, 1982), використання цих найменувань також є дискусійним.

Отже, огляду не певну умовність і загальноприйнятість поняття “absolute”, деякі граматисти пропонують вживати номінації “independent” (Heironimus, 1935, c. 299), "nexus tertiary" (Jespersen, 1949, c. 45), "supplementive clauses" (Biber, 1991) або “closed adjuncts” (Fabricius-Hansen, Haug i Scbø, 2012) на позначення неособоводієслівних і недієслівних клауз з експліцитним суб'єктом.

Для подолання неузгодженості й невизначеності у трактуванні аналізованих синтаксичних одиниць, пропонуємо номінацію “відокремлені неособовідієслівні i недієслівні конструкиії з експліцитним суб'єктом”. Концептуалізацію запропонованого поняття здійснюємо 3 позицій конструкційної граматики (Fillmore, Kay, O’Connor (1988), Boas, Fried (2005), Goldberg A.E. (1995, 2006, 2019) та ін.).

На початку обгрунтуємо вживання елементу “відокремлений” у складі запропонованої номінації. Одним із варіантів перекладу латинського absolutus англійською $є$ "detached from and detachable from the rest» (Morgan, 2013, c. 104), тобто «відокремлений від або той, щзо відокремлюється від” (переклад наш B.Ж.). У впливовій корпусо-керованій граматиці “Longman Grammar of Spoken and Written English" (2007) досліджувані структури належать до класу відокремлених предикативів (detached predicatives), що мають слабкий (loose) зв'язок із ядром речення і типово розташовуються на початку або в кінці речення (Biber, Johanson, Leech, Conrad i Finegan, 1999, c. 137-138).

Я. Рецкер також стверджує, що абсолютний зворот має відокремлений (виділення курсивом наше - В.Ж.) характер та визначає абсолютність як особливий тип синтаксичного зв'язку, що передбачає вільне примикання. Вчений виокремлює такі граматичні ознаки відокремленості, як 1) внутрішній предикативний зв'язок звороту; 2) фіксований порядок слів розташування його компонентів; 3) змістовна та інтонаційна залежність від головного складу (неповна інтонація повідомлення) 
(Реикер, 1953, с. 4). Всі перераховані ознаки притаманні неособоводієслівним та недієслівним клаузам з експліцитним суб'єктом.

М. Ганшина та Н. Василевська (Ganshina i Vasilevskaya, 1964), трактують неособоводієслівні й недієслівні клаузи 3 експліцитним суб'єктом як відокремлену другорядну частину речення, поєднану з головним реченням семантично та інтонаційно, не маючи при цьому експліцитного вираженого синтаксичного зв'язку з ним. Таку ж думку обстоює і Ю. Богоявленська, яка зазначає, що відносна незалежність абсолютної дієприкметникової конструкції від предикативного ядра основного речення відбивається в ії інтонаційному відокремленні, водночас залишаючись у межах його інтонаційних меж завдяки реалізованим обставинним значенням (Богоявленская, 2014, с. 15).

Дж. Керм розглядає аналізовані структури у розділі "Незалежні елементи" (Independent elements) поряд з вигуками, прямим зверненням та абсолютним дієприкметником. Під незалежними елементами граматист розуміє “слова, фрази чи клаузи, що не пов'язані граматично з іншими частинами речення, або, які розташовані окремо, не проявляючи будь-якого граматичного зв'язку" (Curme, 1931, с. 151) (виділення наше - В.Ж.).

Б. Комбет на позначення неособоводієслівних і недієслівних клауз, що містять власний лексичний підмет, послуговується терміном “відокремлені конструкції” (detached constructions) (Combettes, 2005). Услід за Д. Байбером та його співавторами (Biber, Johanson, Leech, Conrad i Finegan, 1999), I. Вестін (Westin, 2002) виокремлює відокремлені аугментовані та неаугментовані дієприкметникові клаузи “'detached' (adverbial) participle clauses”, що трактуються дослідницею як маркери наративного дискурсу.

У баченні С. Томпсон, дієприкметникові звороти (серед яких і ті, які мають власний підмет) вважаються відокремленими, де “відокремлений” означає “...відмежований паузами ... маркований комами на письмі” (Thompson, 1983, c. 43). Суголосні думки висловлює С. Дік, який відносить аналізовані синтаксичні структури до так званих “позаклаузних конституентів" (extraclausal constituents), що включають одиниці, що характеризуються ослабленим зв'язком 3 матричною клаузою та типово відокремлені пунктуаційно (Dik, 1997, c. 381).

Н. Бертон-Робертс розглядає відокремлені ад’юнкти (detached adjuncts), під якими розуміє вирази, “що у певному сенсі “вміщуються" в іншому виразі, але нічого не вносять у його структуру” (Burton-Roberts, 2006, c. 179).

Дослідники (Fabricius-Hansen, Haug i Søebø, 2012, c. 43) вирізняють $з$ одного боку “неінтегровані” (non-integrated), “відокремлені” (detached), “доповнювальні” (supplementary) та “вільно поєднані” (loosely attached) ад’юнкти, а 3 іншого інтегровані (integrated) з матричною клаузою ад’юнкти. Відокремлений статус ад'юнктів позначається пунктуацією на письмі, переважно комою. Автори називають їх (орфографічно) відокремленими ад'юнктами, оскільки такі синтаксичні одиниці відділені від матричної клаузи знаками пунктуації. В усному мовленні відокремлення корелює з просодичним відокремленням, таким чином відокремленні висловлення утворюють власні інтонаційні фрази.

Утворюючи окрему інтонаційну фразу, відокремлені неособоводієслівні й недієслівні клаузи з експліцитним суб'єктом не впливають на інформаційну 
структуру матричної клаузи, а отже не можуть бути фокусом при фоновій матричній клаузі або асоціюватися з фокусними структурами у матричній клаузі. Зауважимо, що орфографічне відокремлення також сигналізує, що досліджувані утворення не є фокусованим релятивом до матричної клаузи, наприклад:

a. The unicorn only stood there, with its horn glittering in the sunshine.

b. \# The unicorn only stood there with its horn glittering in the sunshine.

Пунктуаційна маркованість відокремлення варіюється від мови до мови, а надійні емпіричні розвідки кореляції між орфографічним та просодичним відокремленням наразі практично відсутні (Fabricius-Hansen, Haug i Søbø, 2012, c. 43). Згідно 3 правилами пунктуації сучасної англійської мови неособоводієслівні й недієслівні клаузи 3 експліцитним суб'єктом завжди маркуються пунктуаційними знаками на письмі. Крім ком, зазначені синтаксичні утворення можуть відділятися й іншими знаками, до прикладу, тире, дужками, що зумовлено загальними тенденціями до зміни у кількісному та якісному складі пунктуаційних знаків у сучасній англійській мові та переорієнтації їхньої функціонального навантаження (Салькова $i$ Мачина, 2012, с. 53), а також введенням нових знаків пунктуації, пов'язаних з реалізацією емотивної функції (Салькова і Мачина, 2012, с. 59).

Відзначимо, що у запропонованій номінації елемент “конструкція” використовується не в усталеному традиційному трактуванні як “сполучення слів (одиниць мови), утвореного за граматичними правилами” (Жеребило, 2005, с. 136), "синтаксичне ціле, утворене із поєднаних в мовленні мовних одиниць, що сполучаються внаслідок наявності в них певних граматичних властивостей” (Ахманова, 1969, с. 205) а у новій інтерпретації, прийнятій у Граматиці конструкцій. У світлі теоретико-методологічних положень Граматики конструкцій як граматичного втілення когнітивної лінгвістики (Fillmore, O’Connor (1988), Goldberg (1995, 2019), Östman, Fried (2004), Croft (2008), Hoffmann, Trousdale (2013), Hilpert (2019)), конструкція - некомпозиційний мовний знак, що характеризується єдністю форми та змісту (значення/ функціiі), в якому певний аспект плану вираження (форми) або плану змісту (значення/ функціi) не визначається з форми або змісту його компонентів чи з інших наразі наявних у мові конструкцій та являють собою поєднання визначеного концептуального змісту та конкретної синтаксичної форми (Goldberg, 2019; Hoffmann, 2017; Wasserscheidt, 2019). Досліджувані синтаксичні одиниці схематично репрезентуються:

FORM: [aug/øaug $\left[\mathrm{Subj}_{\mathrm{NP}}\right]\left[\right.$ Pred $\left.\left._{\mathrm{NF} / \mathrm{VL}}\right]\right] \leadsto$ MEANING: $[\ldots . .]_{\text {FUNCTION }}$

де їх значення як структур рівня клаузи трактуємо не як закодовану семантику, а як функцію у дискурсі.

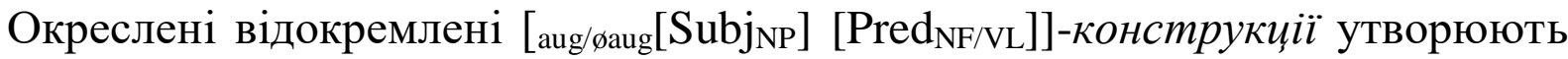
таксономічну конструкційну мережу, яка репрезентується через множинну ієрархію ад'юнктних типів клауз, поєднану з планом відокремлення. Мережа аналізованих конструкиій розгортається навколо конструкційної схеми (constructional scheme), представленої конструкцією найвищого ступеня

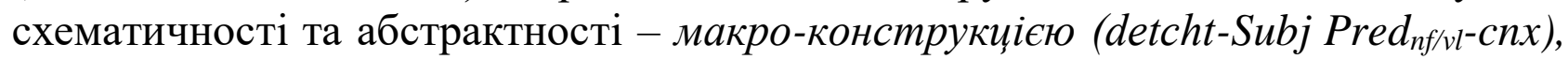
ознаки якої успадковуються менш абстрактними мезо-конструкціями (aug- 
detcht-Subj Pred $_{n f-c n x}$, unaug-detcht-Subj Pred ${ }_{n f}-c n x$, aug-detcht-Subj Pred ${ }_{v l}$-cnx , unaug-detcht-Subj Pred vl-cnx) та індивідуальними мікро-конструкціями (aug/unaug-detcht-Subj Noun $_{\text {Pred }}$ Part $^{-C x n}$, aug/unaug-detcht-Subj Noun $_{\text {Pred }}$ PartI-Cxn, $_{\text {, }}$,

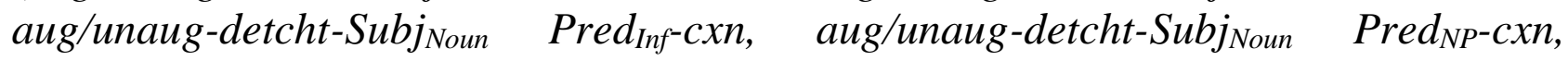
aug/unaug-detcht-Subj $j_{\text {Noun }}$ Pred $_{P P-C x n}$, aug/unaug-detcht-Subj $j_{\text {Noun }}$ Pred $_{A d v P-C x n}$, aug/unaug-detcht-Subj Noun $_{\text {Pred }}$ AP-cxn ...) і втілюються у конкретних реалізованих конструкціях - конструктах (his cheeks burning suddenly, with thick spectacles perched at the very end of his nose, without insects crawling in my hair and vermin nibbling my toes, despite oil being the lifeblood of industrial (modern) society ...).

Підтвердженням правомірності трактування ВКЕС як конструкиій слугують їхні ідіосинкратичні особливості, що не виводяться із властивостей компонентів, як-от: 1) бінарна структура [NP XP]; 2) вторинно-предикативний тип зв'язку між компонентами (перший - вторинний суб' єкт (NP), відмінний від суб'єкта матричної клаузи, другий - вторинний предикат (XP)); 3) визначений спосіб вираження компонентів (вторинний суб'єкт є іменною групою (NP), а вторинний предикат (XP) - неособова форма дієслова (Participle I, Participle II, to-Infinitive) або недієслівна форма (NP, AdjP, AdvP, PP); 4) фіксований порядок компонентів (NP завжди передує XP); 5) визначений тип зв'язку з матричною клаузою (відсутність аугментації (безсполучниково) або обмеженим набором аугменторів (with, what with, without, despite, but, and); 6) рівноправність i взаємозалежність компонентів; 7) інформаційна цілісність; 8) відносна самостійність у структурі речення; 9) пунктуаційна/ інтонаційна відокремленість від матричної клаузи (Жуковська, 2019).

Висновки. Структурна варіативність номінацій, що вживаються на позначення відокремлених неособоводієслівних $\mathrm{i}$ недієслівних клауз 3 експліцитним суб'єктом у граматичних дослідженнях, неоднозначність їхніх поняттєвих обсягів, прив'язаність до наукового контексту конкретного дослідження, а також відсутність чітких критеріїв віднесення синтаксичних одиниць до їх складу, визначає необхідність впровадження і термінологічного витлумачення нового базового поняття, що сприятиме адекватній когнітивноквантитативній операціоналізації та теоретичній актуалізації досліджуваних синтаксичних утворень. Таким поняттям може стати запропонована номінація "відокремлені неособоводієслівні $і$ недієслівні конструкиї з експліцитним суб'єктом” в інтерпретації когнітивно-конструкційного підходу. Однією із перспектив подальших розвідок 3 окресленої проблематики $\epsilon$ здійснення квантитавно-корпусної параметризації лінгвальних властивостей відокремлених конструкцій з експліцитним суб'єктом у сучасній англійській мові.

\section{Список літератури}

Алексеева В. А. Функционирование беспредложных абсолютных конструкций в английском дискурсе. Вестник МГЛУ. Москва, 2011. Выпуск 27 (633). С. 113-121.

Ахманова О. С. Словарь лингвистических терминов. Москва : Издательство «Советская энциклопедия», 1969. 605 с.

Бархударов Л. С. Структура простого предложения современного английского языка. Москва : Высшая школа, 1966. 200 с. 
Богоявленская Ю. В. Синтаксические особенности абсолютных причастных конструкций (на материале французских газетных текстов). Актуальные вопросы переводоведения и практики перевода. Нижний Новгород. 2014. №. 5. С. 15-23.

Жеребило Т. В. Словарь лингвистических терминов. Назрань : ООО «Пилигрим», 2005. 376 с.

Жуковська В. В. Семантика граматичної конструкції: корпусно-квантитативний вимір. Studia Philologica. Київ, 2019. Вип. 13. № 2. С. 28-35. doi.org/10.28925/2311-2425.2019.13.4.

Ильиш Б. И. Структура современного английского языка. Ленинград, М. : Просвещение, 1971. 385 с.

Корунець І. В. Порівняльна типологія української та англійської мови : навч. посіб. Вінниця : Нова книга, 2004. 464 с.

Рецкер Я.И. Стилистико-грамматическое значение абсолютных конструкций в современном английском языке : автореф. дис. ... канд. филол. наук. 10.02.04. Москва, 1953. 23 с.

Салькова М.А., Мачина О.А. Современные тенденции в кодировании смыслов в письменных традиционных и медийных видах дискурса. Вестник МГЛУ. Москва, 2012. Выпуск 27 (660). С. 45-60.

Ярцева В.Н. Исторический синтаксис английского языка. Москва, Ленинград : Издательство Академии наук СССР, 1961. $308 \mathrm{c}$.

Biber D., Johanson S., Leech G., Conrad S., Finegan E. Longman Grammar of Spoken and Written English. London : Longman, 1999. 1204 p.

British National Corpus (BNC-BYU). URL: http://corpus.byu.edu/bnc/ (дата звернення: 24.02. 2021).

Burton-Roberts N. Parentheticals. Encyclopedia of language and linguistics. Amsterdam, 2006. P. 179-182.

Combettes B. Les constructions détachées comme cadres de discours. Langue Française. 2005. № 4. P. 31-44.

Crystal D. A dictionary of linguistics and phonetics (6 ${ }^{\text {th }}$ ed.) Oxford : Blackwell Publishing, 2008. $529 \mathrm{p}$.

Curme G. O. A Grammar of the English Language: SyntaxVol. 3 D.C. Heath and Company, 1931. 616 p.

Dik S. C. The theory of functional grammar. Part II: Complex and derived constructions. Berlin : Mouton de Gruyter, 1997. 477 p.

Fabricius-Hansen C., Haug D.T.T., Sœbø K. J. Closed adjuncts: degrees of pertinence. Big Events, Small Clauses. The grammar of elaboration. Berlin, Boston : De Gruyter, 2012. P. 55-92. DOI: https://doi.org/ $10.1515 / 9783110285864$.

Ganshina M., Vasilevskaya N. English Grammar. Moscow : Vyshaya shkola, 1964. 548 p.

Goldberg A.E. Explain me this: Creativity, Competition, and the Partial Productivity of Constructions. Princeton/ Oxford : Princeton University Press, 2019. 195 p.

Heironimus J.P. The “Ablative Absolute”. The Classical Journal. 1935. Vol. 30, № 5. P. 298-299. URL: https://www.jstor.org/stable/i365691 (дата звернення 24. 02. 2021)

Hoffmann Th. Construction Grammars. The Cambridge Handbook of Cognitive Linguistics. Cambridge : Cambridge University Press. 2017. P. 310-329.

Jespersen O. Analytic syntax. Chicago : University of Chicago Press, 1984. 181 p.

Jespersen O. A modern English grammar on historical principles. Part 4. Syntax. London: Allen \& Unwin. 1949. $528 \mathrm{p}$.

Kortmann, B.: Free adjuncts and absolutes in English: Problems of control and interpretation. London,

New York : Routledge. 1991. 253 p.

Loporcaro M. The Unaccusative Hyposesis and participial absolutes in Italian: Permutter's generalization revised. Rivista di Linguistica. 2003. № 15.2. P. 199-263.

Morgan J. Imperium Book 3. Princeps: Volume 3. CreateSpace Independent Publishing Platform, 2013. 168 p.

Quirk R.S., Greenbaum G., Leech G., Svartvik J. A Comprehensive Grammar of the English Language. London : Longman, 1985. 1779 p.

Ruppel A. Absolute constructions in early Indo-European. N. Y.: Cambridge University Press, 2013. 255 p.

Sakakibara H. WITH-constructions in English. Studies in English Literature, Tokyo : English Literary Society of Japan, 1982. P. 79-95.

Talmy L. Figure and ground in complex sentences. Universals of human language. Stanford : Stanford University Press, 1978. Vol. 4. P. 627-649.

Thompson S. A., Longacre R. E., Hwang J. J. Adverbial clauses. Language Typology and Syntactic Description. Vol. II: Complex constructions. Ed. T. Shopen, Cambridge University Press, 2007. P. 237-300.

Thompson S. A. Grammar and discourse: The English detached participial clause. Discourse perspectives on syntax. New York: Academic Press, 1983. P. 43-64

Visser F. Th. An Historical Syntax of the English Language. Part II: Syntactical Units With One Verb.

Leiden : E.J. Brill, 1972. 1305 p.

Wasserscheidt Ph. Construction Grammar: Basic Principles and concepts. Українське мовознавство. T. 49. 2019. P. 94-116. 
Westin I. Language Change in English Newspaper Editorials. Amsterdam, New York : Ropdopi, 2002. 204 p. Wheelock F. M., LaFleur R. A. Wheelock's Latin (6 ${ }^{\text {th }}$ ed.). New York : HaperCollins, 2005. 560 p.

Zandvoort R. W. A Handbook of English Grammar ( $7^{\text {th }}$ ed.). London : Longman, 1975. 365 p.

\section{References}

Alekseeva, V. A. (2013). Funkcionirovanie predlozhnyh i bespredlozhnyh absolyutnyh konstrukcij v angloyazychnom diskurse [Functioning of augmented and unaugmented absolute constructions in Englishspeaking discourse]. Vestnik MGLU. Moscow, Vypusk 26 (686), 113-121.

Ahmanova, O. S. (1969). Slovar' lingvisticheskih terminov [A dictionaty of linguisitc terms]. Moscow : Izdatel'stvo «Sovetskaya enciklopediya».

Barhudarov, L. S. (1966). Struktura prostogo predlozheniya sovremennogo anglijskogo yazyka [The structure of a simple sentence in English]. Moscow : Vysshaya shkola.

Bogoyavlenskaya, Yu. V. (2014). Sintaksicheskie osobennosti absolyutnyh prichastnyh konstrukcij (na materiale francuzskih gazetnyh tekstov) [Syntactic features of absolute participial constructions (the case of French newspaper texts]. Aktual'nye voprosy perevodovedeniya i praktiki perevoda. Nizhniy Novgorod, №. 5, 15-23.

Zherebilo, T. V. (2005). Slovar' lingvisticheskih terminov [A dictionary of linguistic terms]. Nazran: «Piligrim».

Zhukovska, V. V. (2019). Semantyka hramatychnoi konstruktsii: korpusno-kvantytatyvnyi vymir [Semantics of a grammatical construction]. Studia Philologica. Kyiv, Vyp. 13, № 2, 28-35. doi.org/10.28925/2311-2425.2019.13.4.

Il'ish, B. I. (1971). Struktura sovremennogo anglijskogo yazyka [The structure of present-day English]. Leningrad, Moskva: Prosveshchenie.

Korunets, I. V. (2004). Porivnialna typolohiia ukrainskoi ta anhliiskoi movy: navch. posib [Comparative typology of Ukrainian and English]. Vinnytsia: Nova knyha.

Recker, Ya. I. (1953). Stilistiko-grammaticheskoe znachenie absolyutnyh konstrukcij v sovremennom anglijskom yazyke [Stylisitc and grammatical meaning of absolute constructions in present-day English]. (avtoref. dis. ... kand. filol. nauk. 10.02.04). Moskva.

Sal'kova, M. A., Machina, O. A. (2012). Sovremennye tendencii v kodirovanii smyslov v pis'mennyh tradicionnyh i medijnyh vidah diskursa [Modern tendencies in coding of senses in written traditional and media types of discourse]. Vestnik MGLU. Moskva, Vypusk 27 (660), 45-60.

Yarceva, V. N. (1961). Istoricheskij sintaksis anglijskogo yazyka [Historical syntax of English]. Moskva, Leningrad: Izdatel'stvo Akademii nauk SSSR.

Biber D., Johanson S., Leech G., Conrad S., Finegan E. (1999). Longman Grammar of Spoken and Written English. London: Longman.

British National Corpus (BNC-BYU) [corpus] - URL: http://corpus.byu.edu/bnc/ (дата зверн.: 24.02.2021).

Burton-Roberts N. (2006). Parentheticals. Encyclopedia of language and linguistics. Ed. K. Brown, Amsterdam, 179-182.

Combettes B. (2005). Les constructions détachées comme cadres de discours. Langue Française, № 4, 31-44. Crystal D. (2008). A dictionary of linguistics and phonetics $\left(6^{\text {th }}\right.$ ed.). Oxford : Blackwell Publishing.

Curme G. O. (1931). A Grammar of the English Language: SyntaxVol. 3 D.C. Heath and Company.

Dik S. C. (1997). The theory of functional grammar. Part II: Complex and derived constructions. Berlin: Mouton de Gruyter.

Fabricius-Hansen C., Haug D.T.T, Sœbø K. J. (2012). Closed adjuncts: degrees of pertinence. Big Events, Small Clauses. The grammar of elaboration. Berlin, Boston: De Gruyter, 55-92. DOI: https://doi.org/10.1515/9783110285864.

Ganshina, M., Vasilevskaya, N. (1964). English Grammar. Moscow : Vyshaya shkola.

Goldberg, A. E. (2019). Explain me this: Creativity, Competition, and the Partial Productivity of Constructions. Princeton/ Oxford: Princeton University Press.

Heironimus, J. P. (1935). The "Ablative Absolute”. The Classical Journal, Vol. 30, № 5, 298-299.

URL: https://www.jstor.org/stable/i365691 (дата звернення 24. 02. 2021).

Hoffmann, Th. (2017). Construction Grammars. The Cambridge Handbook of Cognitive Linguistics. Cambridge: Cambridge University Press, 310-329.

Jespersen, O. (1984). Analytic syntax. Chicago: University of Chicago Press.

Jespersen, O. (1949). A modern English grammar on historical principles. P.4. Syntax. London: Allen \& Unwin.

Kortmann, B. (1991). Free adjuncts and absolutes in English: Problems of control and interpretation. London, New York: Routledge.

Loporcaro, M. (2003). The Unaccusative Hyposesis and participial absolutes in Italian: Permutter's generalization revised. Rivista di Linguistica, № 15.2, 199-263. 
Morgan, J. (2013). Imperium Book 3. Princeps: Volume 3. CreateSpace Independent Publishing Platform.

Quirk, R. S., Greenbaum, G., Leech, G., Svartvik, J. (1985). A Comprehensive Grammar of the English Language. London: Longman.

Ruppel, A. (2013). Absolute constructions in early Indo-European. New York: Cambridge University Press.

Sakakibara, H. (1982). WITH-constructions in English. Studies in English Literature, Tokyo: English Literary Society of Japan, 79-95.

Talmy, L. (1978). Figure and ground in complex sentences. Universals of human language. Stanford: Stanford University Press, Vol. 4, 627-649.

Thompson, S. A., Longacre, R. E., Hwang, J. J. (2007). Adverbial clauses. Language Typology and Syntactic Description. Vol. II: Complex constructions. Ed. T. Shopen, Cambridge: Cambridge University Press, 237-300.

Thompson, S. A. (1983). Grammar and discourse: The English detached participial clause. Discourse perspectives on syntax. New York: Academic Press, 43-64.

Visser, F. Th. (1972). An Historical Syntax of the English Language. Part II: Syntactical Units With One Verb. Leiden: E.J. Brill.

Wasserscheidt, Ph. (2012). Construction Grammar: Basic Principles and concepts. Ukrainske movoznavstvo, T. 49, 94-116.

Westin, I. (2002). Language Change in English Newspaper Editorials. Amsterdam, New York: Ropdopi.

Wheelock, F. M., LaFleur, R. A. (2005). Wheelock's Latin (6 ${ }^{\text {th }}$ ed.). New York: HaperCollins.

Zandvoort, R. W. (1975). A Handbook of English Grammar ( $7^{\text {th }}$ ed.). London: Longman.

\title{
VARIABLY-INTERPRETIVE POTENTIAL OF THE LITERARY TEXT AND ITS REALIZATION IN THE TRANSALTION (BASED ON CHUCK PALAHNIUK'S NOVEL "FIGHT CLUB") \\ ВАРІАТИВНО-ІНТЕРПРЕТАЦЙНИЙ ПОТЕНЦАЛ ХУДОЖНЬОГО ТВОРУ ТА ЙОГО РЕАЛІЗАЦІЯ У ПЕРЕКЛАДІ (НА ОСНОВІ РОМАНУ ЧАКА ПОЛАНІКА "БІЙЦІВСЬКИЙ КЛУБ")
}

\author{
Анна ЗАДОРОЖНА, Василь БЯЛИК \\ Чернівецький національний університет імені Юрія Федьковича \\ zadorozhna.anna@chnu.edu.ua, v.bialyk@chnu.edu.ua \\ ORCID ID 0000-0002-8571-5296, ORCID ID 0000-0001-7428-7145
}

The article examines the variability of translation of the text of fiction as performed by different translators. The purpose of the work is to study and identify the diversity of the translation strategies and features of their application in the translation of a literary text. The method of comparative analysis proved to be effective in the scientific investigation. The subject of the research is a literary text, its original and translation. The postulates of translation theorists on linguistic variability and multiplicity of translations have been outlined. The subjective-objective activity of the translator as a mediator in bilingual communication was highlighted. The peculiarities of Chuck Palahniuk's writing style have been determined and the preservation of the author's individual style in Ukrainian translations has been analyzed. A comparative analysis of fragments of the translation of the literary text made by Ukrainian translators has been carried out. It was discovered that in the process of translation the translator relies not only on his knowledge of the languages, but also on the general knowledge of other areas of human life. It has been established that the perception and understanding of the text by the recipients depends on how the translator interprets the text of the original and how adequately s/he conveys its context and whether s/he is able to preserve the author's style. The study was based on the novel "Fight Club" by the contemporary American writer Chuck Palahniuk and its translations into Ukrainian by Illia Strongovskyi and Oleh Lesko. It has been proved 